JMI Vol. 42 No. 2, Desember 2020

METAL INDONESIA

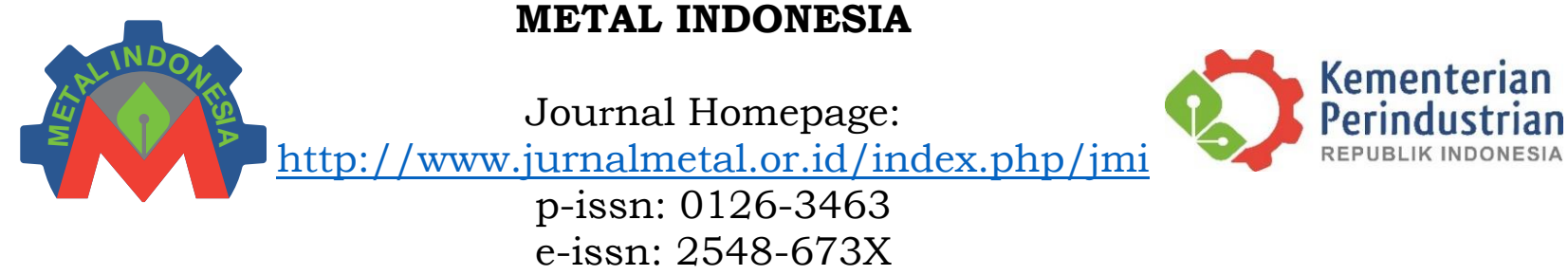

\title{
PENGUKURAN GEOMETRI BENDA TIPIS (SUDU/BLADE) DENGAN 3D LASER SCANNER BERDASARKAN REFERENSI VEKTOR DAN PEMAKAIAN BENDA PEMBANDING
}

\section{GEOMETRICAL MEASUREMENT OF THIN OBJECTS (BLADES) WITH 3D LASER SCANNER BY THE USE OF REFERENCE VECTORS AND COMPARISON OBJECTS}

\author{
Mas Sahid BHM \\ Balai Besar Logam dan Mesin, Kementerian Perindustrian \\ Jl. Sangkuriang No. 12 Bandung 40135 \\ E-mail : massahid@kemenperin.go.id
}

\begin{abstract}
Abstrak
3D laser scanner merupakan alat ukur yang digunakan untuk mengambil data objek geometrik 3D secara cepat dan "akurat" dengan metode pengukuran non-kontak. Dalam pengambilan data, akan diperoleh data kumpulan titik (point clouds) yang selanjutnya diolah menjadi bentuk khas sebagai model permukaan (surface) maupun padat (solid) yang selanjutnya dapat digunakan untuk berbagai keperluan seperti: analisis geometrik, manufaktur, maupun inspeksi. Sebelum surface maupun solid model terbentuk, diperlukan pemrosesan data kumpulan titik yang telah diambil dengan cara penyatuan (fitting) dan proses editing mesh lainnya. Bagi objek dengan bentuk yang tipis seperti: sudu/blade proses fitting menjadi tidak mudah, karena adanya bentuk kurva yang terbuka antara kurva objek bagian depan dan belakang sudu ketika dilakukan penggabungan data. Proses fitting biasanya membutuhkan referensi minimal tiga buah titik. Pada penelitian ini fungsi referensi titik tersebut digantikan dengan referensi berupa sumbu/vektor. Referensi sumbu/vektor ini diperoleh dengan meletakkan benda berbentuk tabung di sekeliling objek yang akan dilakukan scanning. Selain objek tabung juga digunakan objek lain sebagai perbandingan dalam hal kemudahan proses pengukurannya. Hasil pengubahan referensi ini memperlihatkan nilai rata-rata persentase penyimpangan berdasarkan referensi sumbu adalah $0,935 \%$, sedangkan rata-rata persentase penyimpangan dengan referensi 'pick point' yaitu adalah $8,77 \%$. Jadi, pengubahan acuan referensi penggabungan data kumpulan titik (point clouds) dari tiga titik menjadi vektor akan menaikkan akurasi (ketelitian/kebenaran) proses pengukuran dengan $3 D$ laser scanner.
\end{abstract}

Kata Kunci: 3D laser scanner, sudu/blade, kesalahan fitting, referensi sumbu/vektor

\begin{abstract}
$3 D$ laser scanner is a measuring equipment used to retrieve $3 D$ geometrical object data quickly and "accurately" using the non-contact measurement method. Within the data retrieval, point clouds are obtained then being processed into surface and solid models that can be used for various purposes such as: geometrical analysis, manufacturing, and inspection. Before forming the surface or solid model, it is necessary to process the point-clouds data that have been taken by combining (fitting) and other mesh editing processes. For objects with thin shapes, such as blades, the fitting process become difficult, due to the occurent of open curves between the front and back curves of the object when data is being combined.
\end{abstract}


The fitting process usually requires reference of at least three points. This study try to replace the three points reference by an axis/vector reference. This axis/vector reference is obtained by placing a tubular object around the object to be scanned. Beside tubular object, other objects also being used as a comparison purpose in facilitating the measurement process. By changing with this reference the result shows that the average deviation percentage based on the axis reference is $0.935 \%$, while the average deviation percentage with the 'pick point' reference is $8.77 \%$. Therefore, the changing of the reference in combining the pointclouds data from the three points into vector/axis will increase the accuracy of the $3 D$ laser scanner method.

Keywords : 3D laser scanner, blades, fittings error, axis/vector references

\section{PENDAHULUAN}

Alat ukur $3 D$ laser scanner digunakan untuk mendapatkan data (surface maupun solid model) pada sebuah objek geometrik 3D, dengan kecepatan pengambilan data dan kemudahan dalam pengolahan hasil scan adalah merupakan keunggulan yang dimiliki oleh alat ukur ini. Selain dapat digunakan untuk memindai (scanning) bentuk yang kompleks alat ini biasanya berukuran ringkas sehingga mudah dipindahkan/dibawa (portabel).

Hasil yang diperoleh proses $3 D$ scan ini berupa kumpulan koordinat titik yang harus diolah lagi sebelum menjadi surface/solid model. Secara umum data hasil scan yaitu data kumpulan titik (point clouds) diolah menjadi mesh, kurva (curve), dan akhirnya menjadi solid/surface model $(\mathrm{H}$. Yu and Wang 2014). Apabila hasil mesh yang diperoleh sudah cukup bagus maka proses pembuatan kurva dapat diabaikan yaitu dengan menggunakan fitur/menu autosurface. Untuk mendapatkan mesh objek dari data titik (point clouds) diperlukan proses penggabungan data titik atau disebut dengan fitting (Suryo et al. 2013).

Proses fitting yang baik akan menghasilkan bentuk dan ukuran data virtual sesuai dengan ukuran dan bentuk objek sebenarnya, sehingga keberhasilan proses fitting akan sangat menentukan kesalahan ukuran maupun bentuk pada data mesh yang diperoleh. Untuk memperkecil kesalahan tersebut, $3 D$ laser scanner biasanya dilengkapi dengan referensi berupa stiker khusus yang dapat ditempel pada objek yang akan diukur.

Pada pengambilan data scan untuk objek yang berukuran tipis yaitu pada sudu turbin (turbine blade) seringkali diperoleh hasil fitting yang tidak pas antara data sisi muka dan belakang yang berupa celah pada salah satu atau kedua ujung pertemuan sudu/blade tersebut (Gambar 1) (Dewi and Purnama 2018). Dengan ketidaksempurnaan pada proses fitting ini akan membuat proses pemodelan menjadi lebih panjang. Proses fitting hasil scan objek didahului dengan penentuan minimal 3 buah referensi titik yang memiliki posisi yang sama (Chen, Gao, and He 2014). Pada penelitian ini sebagian titik referensi diganti dengan referensi berupa sumbu yang diperoleh dari benda sebagai alat bantu yang berbentuk tabung yang diletakkan di sekeliling objek yang akan diukur.

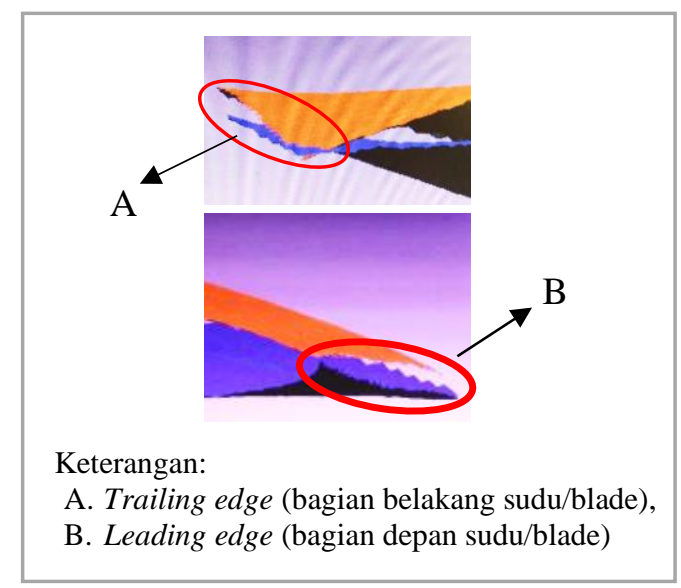

Gambar 1. Kelemahan fitting point clouds bila digunakan referensi 3 titik

\section{METODOLOGI PENELITIAN}

Dalam penerapan metode fitting (penggabungan data kumpulan titik) yang menggunakan metode sumbu/vektor ini, diperlukan bahan dan peralatan sebagai berikut: sudu/blade sebagai objek ukur, botol parfum kecil sebagai benda tabung yang sumbunya akan dijadikan sebagai vektor referensi, objek/benda lain sebagai pembanding benda tabung, cairan developer, set alat ukur $3 D$ scanner, vernier calipers sebagai alat ukur langsung, serta komputer pengolah data. Alat ukur $3 D$ scanner yang digunakan adalah Konica Minolta Vivid $9 i$ 
yang dilengkapi dengan rotary module, adapun Software pengolah datanya adalah Geomagic. Penelitian ini dilakukan di Divisi Perancangan Keteknikan, Balai Besar Logam dan Mesin Bandung, Mei s.d. Juli 2020.

Ruang lingkup penelitian ini berupa proses pengukuran blade secara parsial/tidak utuh, yaitu dengan mengambil data kumpulan titik objek yang diputar 1 siklus menggunakan rotary module kemudian menggabungkan bagian objek sisi bawah (lower surface) dan objek sisi atas (upper surface) berdasarkan sumbu yang diperoleh dari referensi botol/tabung yang digunakan. Penempatan referensi botol/tabung (parfum) diusahakan berada di sekeliling objek sudu/blade pada 3 lokasi menyebar di satu lingkaran yang sama, lihat Gambar 2.

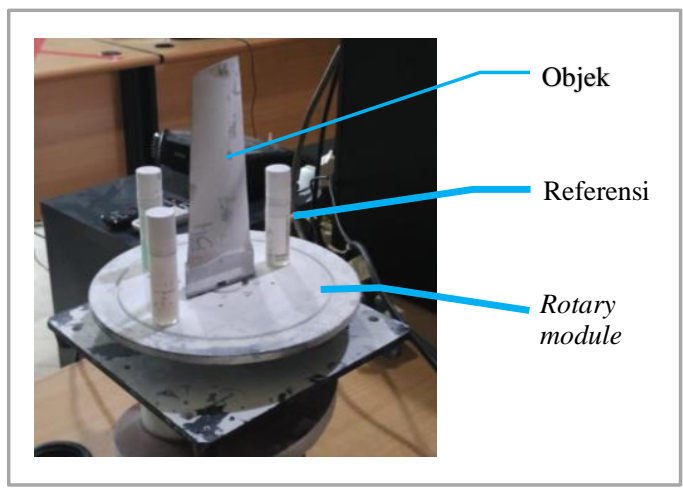

Gambar 2. Penempatan sudu/blade di pertengahan meja putar dikelilingi tiga silinder referensi yang diletakkan menyebar di satu lingkaran dengan pusat yang diusahakan sama dengan sumbu blade

Untuk melakukan proses fitting dengan metode sumbu tersebut dan menjamin kesesuaiannya dengan ukuran riil objek, diperlukan "objek/benda" pembanding (Gambar 3) yang memiliki dimensi yang dapat diukur dengan relatif mudah serta terjaga ketelitiannya (tidak mudah salah) seperti panjang, lebar, dan/atau tinggi yang merupakan elemen geometrik benda pembanding. Perlu dicatat, pengukuran radius sebaiknya dihindari karena mengukur radius secara langsung sulit dilakukan dengan teliti. Teknik yang digunakan selama proses scanning maupun pengolahan data objek pembanding adalah serupa dengan yang dilakukan bagi objek sudu/blade. Adapun hasil akhir pengolahan data "objek pembanding" adalah dimensi objek ukur yang dapat dibandingkan dengan ukuran sebenarnya elemen geometrik ybs. yaitu beberapa bagian "objek pembanding" yang dipilih (diukur dengan alat ukur langsung seperti vernier caliper atau micrometer).

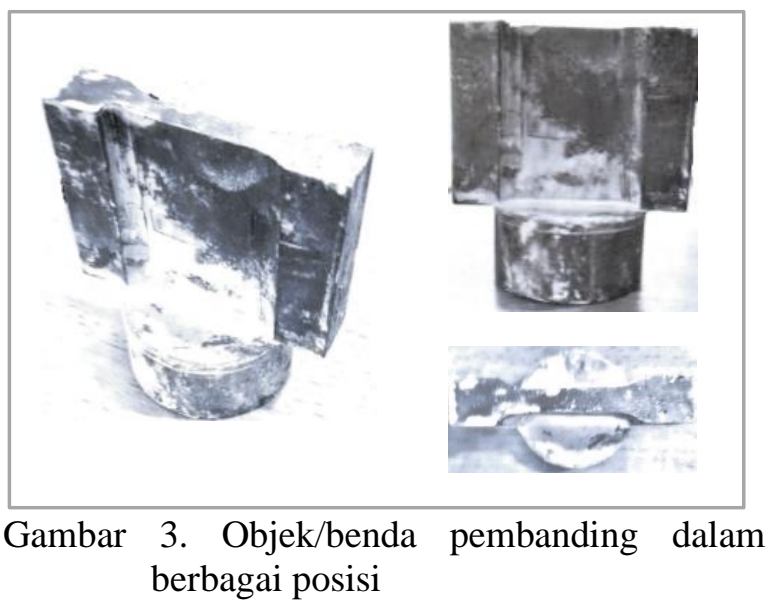

Secara umum metodologi penelitian kesesuaian/kebaikan pemakaian vektor referensi yang diturunkan dari benda yang berupa tabung bagi pengukuran objek ukur dengan geometri permukaan yang kompleks seperti sudu/blade ini terdiri atas 4 (empat) bagian utama:

a. Persiapan/preparasi objek

Tahap persiapan/preparasi difokuskan pada penyiapan objek ukur (sudu/blade dan objek pembanding) dan tabung/silinder referensi, pembersihan permukaan objek, penyemprotan menggunakan developer (cairan pembersih) serta pengaturan lokasi dan orientasi objek ukur dan tabung sebagai benda referensi pada meja putar.

b. Pengambilan data kumpulan titik objek

Proses pengambilan data kumpulan titik objek ukur menggunakan $3 D$ laser scanner, rotary module dan pemakaian software yang tersedia di komputer alat ukur. Metode pengambilan data bagi objek sudu/blade maupun objek pembanding hanya dilakukan sebanyak 2 (dua) kali yaitu bagian muka/depan/atas dan belakang/bawah dengan mengeset rotary module pada dua harga yaitu $0^{\circ}$ dan $180^{\circ}$.

Perlu dicatat bahwa pada proses fitting data konvensional (berbasis referensi titik) dibutuhkan proses pengambilan data yang lebih dari dua kali untuk sekali siklus putaran 
(scan sudu/blade). Jadi, pemakaian sumbu benda tabung referensi akan mempercepat proses pengukuran.

c. Pengolahan data kumpulan titik (point clouds)

Tahap pengolahan data kumpulan titik bagi objek yang dimaksud adalah proses penggabungan dua permukaan objek untuk menjadi sebuah data satu kesatuan utuh guna melakukan proses berikutnya yaitu pembuatan surface/solid model, analisis penyimpangan, maupun validasi pengukuran.

Menurut (C. Yu, Ji, and Xue 2020) salah satu metode yang digunakan untuk mendapatkan sumbu/vektor benda berbentuk silinder adalah dengan memotong silinder dengan bidang rata, kecuali bila dua bidang ini saling tegaklurus, garis perpotongannya umumnya akan berbentuk elips, sehingga dihasilkan dua titik pusat. Oleh sebab itu pada penelitian ini untuk mendapatkan sumbu/vektor referensi bagi botol yang berbentuk silinder digunakan fitur REGION (Yusmira 2016) pada software Geomagic. Dengan teknik tersebut maka dengan cepat akan diperoleh referensi berupa sumbu/vektor pada masing-masing silinder referensi. Selanjutnya berdasarkan sumbu referensi ini dilakukan proses penggabungan data bagian depan dan bagian belakang objek ukur.

\section{d. Metode analisis}

Pada tahap ini dilakukan pengukuran dengan metode konvensional (pick point) sehingga hasil fitting dua permukaannya dapat dibandingkan dengan hasil pengukuran langsung pada objek yang sama guna memeriksa adanya perbedaan atau kesamaan yang bermakna (significant) di antara kedua metode ini.

Skema/flowchart metodologi penelitian secara detail ditunjukkan pada Gambar 4, sedangkan proses penelitian untuk mendapatkan gabungan kumpulan data titik (point clouds) pada masing-masing objek ditunjukkan seperti Gambar 5. Output yang diharapkan dalam $3 D$ scanning adalah berupa data titik yang telah dilakukan penggabungan/fitting. Proses point clouds fitting ini akan menjadi kunci dalam menentukan ketelitian (kebenaran) hasilnya.

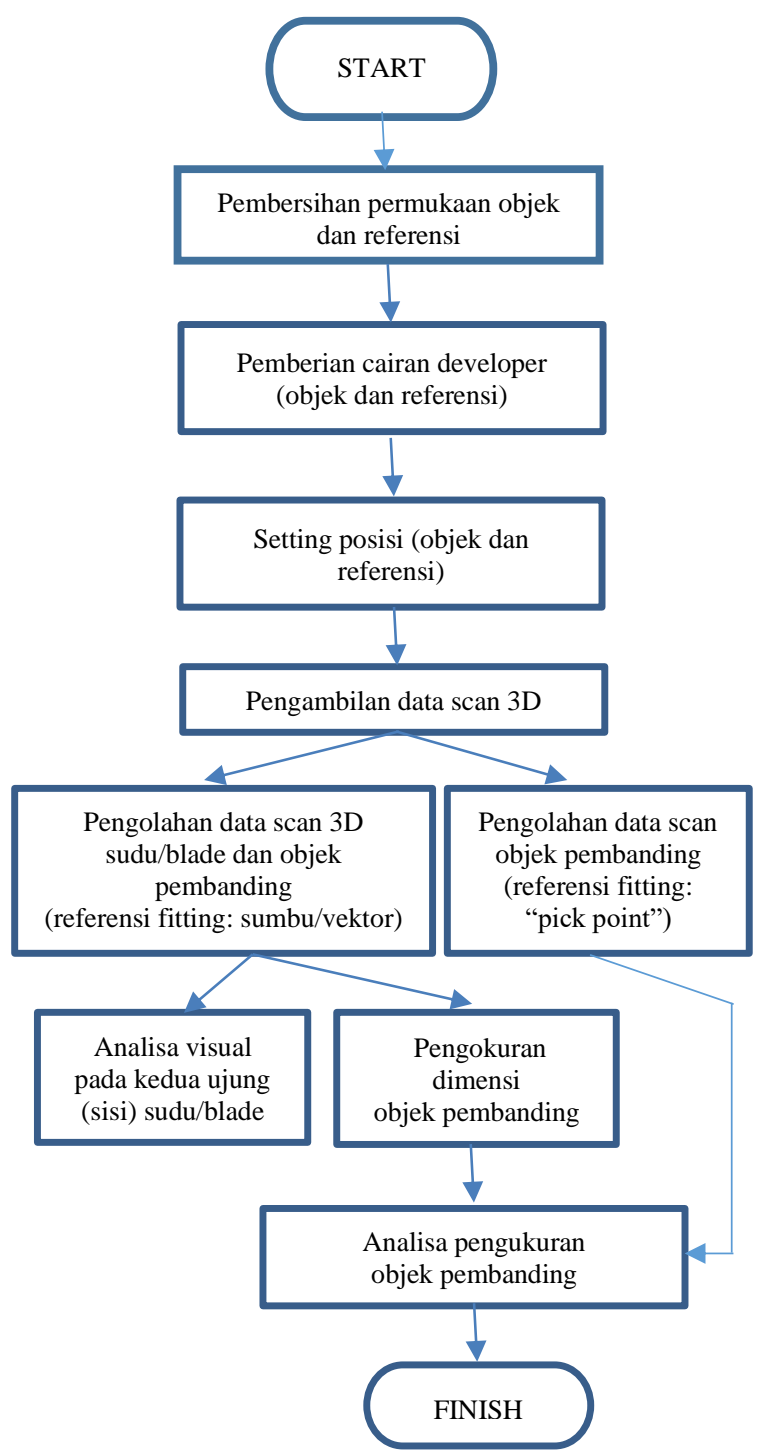

Gambar 4. Diagram alir metodologi penelitian $3 D$ laser scanner menggunakan referensi vektor dan objek pembanding

Untuk

mengimplementasikan penggabungan data berbasis sumbu/vektor dibutuhkan referensi pendukung berupa titik (point) maupun beberapa datum yang didefinisikan pada software pengolah data yang digunakan di dalam proses editing point clouds. Fungsi referensi tambahan ini merupakan persyaratan yang diminta oleh software pengolah data titik untuk menyelesaikan proses penggabungan dua buah data titik. Selain itu, dalam penelitian ini tidak dilakukan pengubahan pada data hasil scan seperti: healing, editing 
boundaries, smoothing dan decimate (Pujiyanto 2014), dengan kata lain, data dipakai seperti apa adanya.

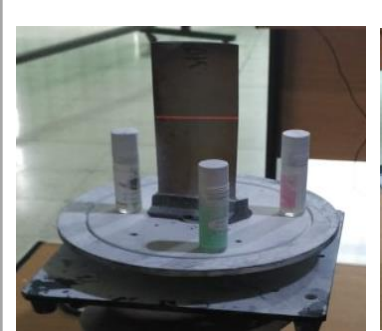

(1)

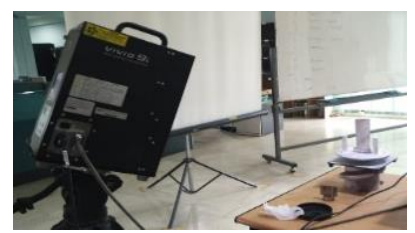

(2)

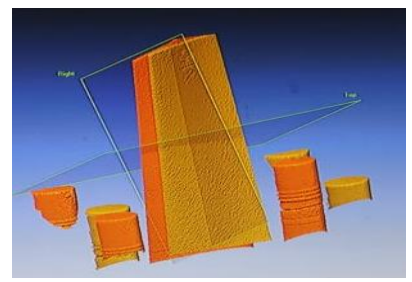

(3)

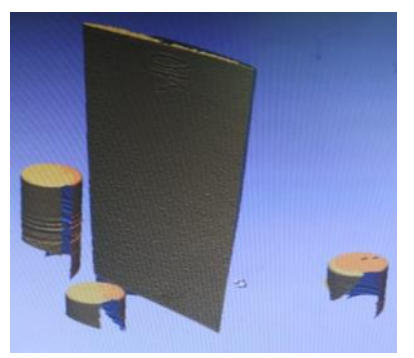

(4)

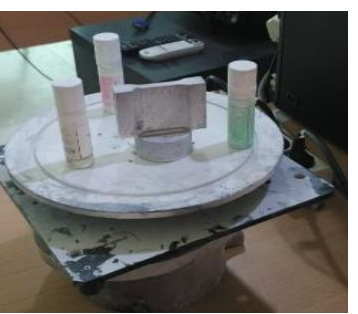

(1)

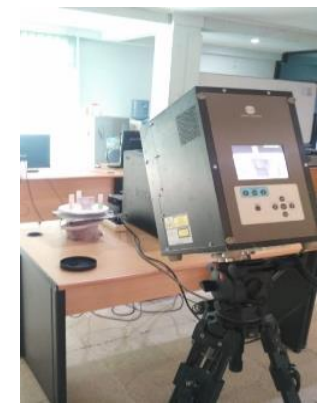

(2)

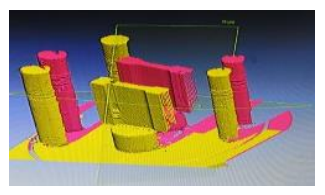

(3)

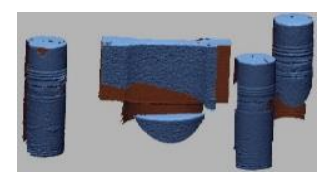

(4)

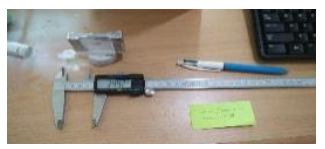

(5)

a. scan sudu/blade

b. objek pembanding

Gambar 5. Tahapan proses pengukuran objek sudu dan objek pembanding: (1) setting awal; (2) proses scan objek; (3) data titik/point clouds; (4) fitting data titik; (5) pengukuran linier elemen geometrik terpilih pada objek pembanding

\section{HASIL DAN PEMBAHASAN}

Di dalam proses pengambilan, pengolahan, dan analisis data hasil scan (point clouds) ini melibatkan dua buah objek yaitu sudu/blade dan benda lain sebagai objek pembanding. Output penelitian pada objek sudu/blade berupa pengamatan secara visual pada bagian sambungan antara sisi dalam dan sisi permukaan luar. Sementara itu, pada objek pembanding pengamatan ditekankan pada ukuran elemen geometrik yang terpilih (yang diukur dengan alat ukur langsung pada benda aktual) pada data titik (point clouds) yang telah dilakukan fitting/penggabungan.

Pada pengolahan data titik hasil scanning sudu/blade yang menggunakan referensi fitting berupa sumbu diperoleh hasil bahwa pada kedua ujung depan/belakang (leading and trailing edge) masih tetap terbuka. Oleh karena itu dilakukan segmentasi (Wang et al. 2014) untuk mengamati gap/celah (atau interferensi) pada leading edge (sisi bagian depan) dan trailing edge (sisi belakang). Panjang bagian sudu yang disegmentasikan sebanyak 6 (enam) bagian seperti yang ditunjukkan pada Gambar 6 .

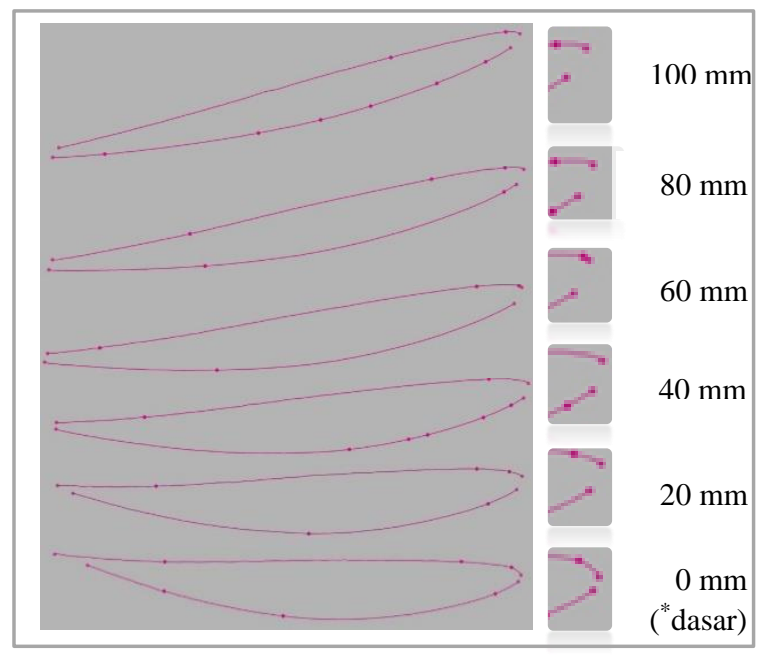

Gambar 6. Segmentasi dan profil penampang sudu/blade hasil pengolahan data scanning

Berdasarkan hasil pengamatan secara visual, terlihat bahwa pada segmentasi 0 dan 20 mm baik untuk sisi leading edge maupun trailing edge Segmentasi dan profil penampang sudu/blade hasil pengolahan data scanning masih relatif normal, akan tetapi terdapat gap yang cukup besar terutama pada sisi trailing edge pada segmentasi $40 \mathrm{~mm}$ sampai dengan $100 \mathrm{~mm}$. Adanya gap yang besar ini dikarenakan kurva luar dan dalam (sisi belakang/trailing edge) memiliki 
orientasi yang hampir sejajar dengan ujung yang tak melengkung/membelok untuk saling bertemu. Bagi ujung seperti ini apabila diberikan penambahan kurva agar mereka saling berpotongan bisa berdampak pada penambahan ukuran/dimensi aksial pada segmen tersebut.

Pada pengukuran hasil penggabungan data titik (point clouds) "objek pembanding" menggunakan alat ukur maupun secara software (proses fitting menggunakan referensi sumbu/vektor dan titik/pick point), dapat dilihat pada Tabel 1 berikut. Berdasarkan data hasil pengukuran diperoleh kondisi anomali terbesar pada penyimpangan ukuran antara fitting dengan metode sumbu dan pick point yaitu pada dimensi lebar dan diameter 'objek pembanding'. Persentase penyimpangan proses point clouds fitting dengan metode referensi sumbu untuk dimensi lebar diperoleh nilai $-2,30 \%$ s.d. $-1,45 \%$ sedangkan metode fitting 'pick point' diperoleh nilai $16,51 \%$ s.d. $20,81 \%$. Adapun nilai persentase penyimpangan untuk dimensi diameter dengan metode sumbu dan 'pick point' secara berurutan adalah $1,01 \%$ dan $7,39 \%$. Nilai rata-rata persentase penyimpangan berdasarkan referensi sumbu adalah $0,935 \%$, sedangkan rata- rata persentase penyimpangan dengan referensi 'pick point' adalah $8,77 \%$.

Sebagian dimensi pada 'objek pembanding' seperti dimensi panjang dan tinggi memiliki nilai penyimpangan ukuran yang relatif konstan, berbeda halnya pada dimensi lebar dan diameter yang menghasilkan nilai penyimpangan yang tidak konstan. Pada metode scanning pengambilan data hanya dilakukan sebanyak 2 (dua) kali pada bagian muka dan belakang dengan perbedaan sudut rotary stage table yang digunakan sebesar $180^{\circ}$, sehingga pada 1 siklus scan hanya akan menghasilkan dimensi panjang dan tinggi serta sebagian bentuk diameter. Adapun dimensi lebar merupakan parameter kunci keberhasilan proses fitting karena dimensi/ukuran lebar objek ini tersusun dan didominasi oleh beberapa referensi yang dipakai pada proses fitting serta sebagian kecil data titik yang dihasilkan pada proses scanning 3D objek. Berbeda halnya dengan dimensi lebar, dan diameter yang ditentukan oleh proses fitting dan scanning objek dalam porsi yang seimbang. Proses scanning objek diameter akan menghasilkan kurva potongan (segmentasi) berbentuk lingkaran dari objek silinder pada satu sisi dan dari sisi silinder yang lainnya. Karena hasil fitting pada dimensi objek juga dipengaruhi oleh proses pengambilan data/scanning maka penyimpangan diameter akan lebih kecil dibandingkan dengan penyimpangan dimensi lebar yang hampir murni dibentuk oleh proses fitting.

Perbedaan antara proses pengukuran yang dihasilkan pada dimensi lebar (Gambar 7) dan diameter (Gambar 8) ditunjukkan sebagai berikut.

Tabel 1. Pengukuran objek/benda pembanding

\begin{tabular}{|c|c|c|c|c|c|c|c|c|}
\hline \multirow{2}{*}{ No. } & \multirow{2}{*}{ Ukuran } & \multirow{2}{*}{$\begin{array}{l}R i i l^{*} \\
(\mathrm{~mm})\end{array}$} & \multicolumn{2}{|c|}{ Referensi** } & \multicolumn{2}{|c|}{$\begin{array}{l}\text { Penyimpangan } \\
\text { (Riil-Referensi) }\end{array}$} & \multicolumn{2}{|c|}{$\begin{array}{c}\text { Prosentase } \\
\text { penvimpangan }\end{array}$} \\
\hline & & & $\begin{array}{l}\text { Sumbu } \\
(\mathrm{mm})\end{array}$ & $\begin{array}{l}\text { Pick point } \\
(\mathrm{mm})\end{array}$ & $\begin{array}{c}\text { Sumbu } \\
(\mathrm{mm})\end{array}$ & $\begin{array}{l}\text { Pick point } \\
(\mathrm{mm})\end{array}$ & $\begin{array}{c}\text { Sumbu } \\
(\%)\end{array}$ & $\begin{array}{l}\text { Pick point } \\
\text { (\%) }\end{array}$ \\
\hline 1 & Panjang & 60,02 & 58,9179 & 58,9923 & 1,1021 & 1,0277 & 1,84 & 1,71 \\
\hline 2 & Lebar & 12,02 & $\begin{array}{l}12,297 \\
12,1948\end{array}$ & $\begin{array}{l}9,5191 \\
10,0355\end{array}$ & $\begin{array}{l}-0,277 \\
-0,1748\end{array}$ & $\begin{array}{l}2,5009 \\
1,9845\end{array}$ & $\begin{array}{l}-2,30 \\
-1,45\end{array}$ & $\begin{array}{l}20,81 \\
16,51\end{array}$ \\
\hline 3 & Tinggi & $45,35-45,60$ & $\begin{array}{l}43,9572 \\
44,0791\end{array}$ & $\begin{array}{l}43,9166 \\
44,2166\end{array}$ & $\begin{array}{l}1,3928 \\
1,5209\end{array}$ & $\begin{array}{l}1,4334 \\
1,3834\end{array}$ & $\begin{array}{l}3,17 \\
3,34\end{array}$ & $\begin{array}{l}3,16 \\
3,03\end{array}$ \\
\hline 4 & Diameter & 40 & 39,5956 & 37,043 & 0,4044 & 2,957 & 1,01 & 7,39 \\
\hline \multicolumn{7}{|c|}{ Rata-rata } & $0,93 \%$ & $8,77 \%$ \\
\hline
\end{tabular}

Keterangan:

* Pengukuran menggunakan vernier caliper/jangka sorong

** Pengukuran menggunakan fitur yang disediakan oleh software 
Tahapan pengukuran pada dimensi lebar dimulai dengan melakukan pendefinisian garis berdasarkan section yang telah diperoleh (garis warna magenta/merah) kemudian dilakukan proses penyejajaran kedua garis tersebut supaya muncul nilai lebar (garis warna cyan/biru). Dimensi lebar yang diperoleh dari proses scanning dapat diabaikan karena telah diganti dengan profil section dimensi tinggi yang telah dilakukan pada proses fitting/penggabungan data antara bagian muka dan belakang objek. Bagi pengukuran dimensi diameter/radius dilakukan dengan melakukan pendefinisian kurva lingkaran berdasarkan section point clouds berbentuk tabung (objek). Karena data scan yang diperoleh terdiri atas dua bagian (depan dan belakang) maka diperoleh 2 (dua) buah lingkaran. Kurva lingkaran berwarna biru merupakan hasil pendekatan data scan objek pada bagian depan, sedangkan kurva lingkaran putus-putus adalah pendekatan data scan objek bagian belakang. Hasil penggabungan kedua kurva lingkaran adalah lingkaran berwarna merah.

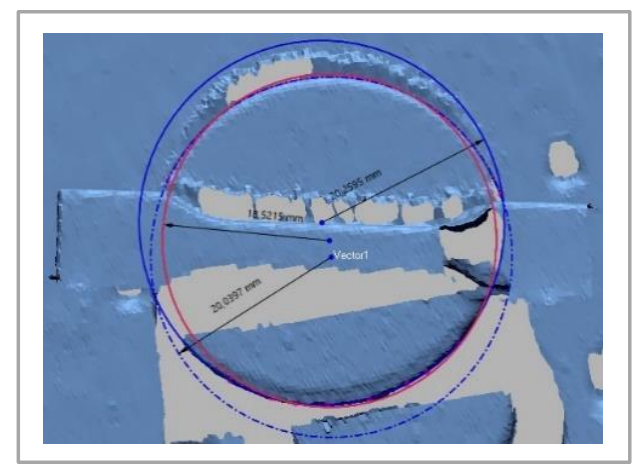

Gambar 7. Pengukuran dimensi lebar pada 'objek pembanding'

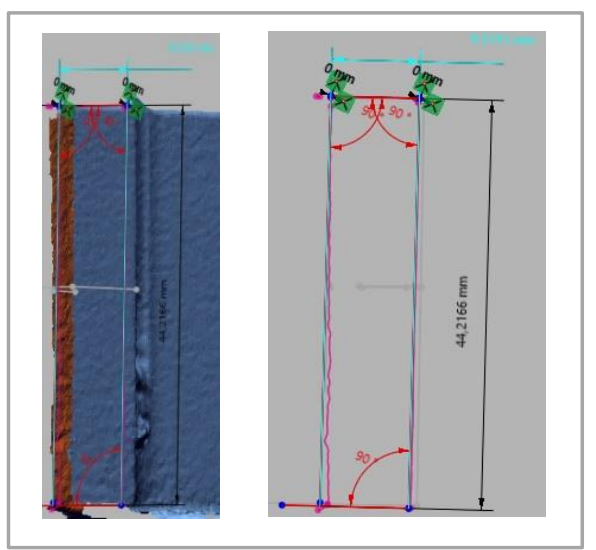

Gambar 8. Proses pengukuran dimensi diameter 'objek pembanding'
Jika perhitungan penyimpangan pada objek pembanding (Tabel 1) diterapkan pada hasil segmentasi pada sudu/blade terutama pada sisi belakang/trailing edge, maka diperoleh nilai gap sebagaimana ditunjukkan pada Tabel 2.

Supaya proses fitting efektif (tujuan tercapai) bagi sudu/blade ybs. terlebih dahulu perlu dilakukan pengecekan pada dimensi "B" karena ukuran ini ekuivalen dengan dimensi lebar pada "objek pembanding". Nilai rata-rata pada dimensi "B" diperoleh sebesar 1,02 mm, sedangkan nilai rata-rata penyimpangan untuk dimensi lebar (objek pembanding) adalah $1,875 \%$, maka nilai penyimpangan pada sisi lebar (X) sudu/blade dengan rata-rata lebar riil $50 \mathrm{~mm}$ dapat ditentukan sebagai berikut:

$$
X=S . Y
$$

dimana:

$\mathrm{X}=$ nilai penyimpangan pada sisi yang akan diukur

$\mathrm{S}=$ nilai persentase penyimpangan

$\mathrm{Y}=$ sisi ukur

Nilai penyimpangan pada sisi lebar berdasarkan persamaan (1) di atas diperoleh sebesar $-0,375 \mathrm{~mm}$, sedangkan nilai rata-rata gap (sisi lebar) pada sudu/blade adalah 1,02 mm sehingga terdapat perbedaan pengukuran pada sisi lebar sebesar $0,645 \mathrm{~mm}$. Tanda minus yang ditunjukkan pada persentase penyimpangan merupakan tanda bahwa hasil pengukuran dengan memakai software lebih besar dibandingkan nilai pengukuran riil. Dengan demikian mengacu pada metode fitting dengan referensi sumbu pada objek pembanding, maka kurva bezier bagian dalam sudu/blade harus digeser menuju kurva luar sudu/blade sebesar -0,645 mm agar bentuk dan ukuran sudu/blade mendekati nilai yang sebenarnya.

Tabel 2. Ukuran gap "trailing edge" sudu/blade

\begin{tabular}{|c|c|c|c|}
\hline $\begin{array}{c}\text { Segmen ke- } \\
\ldots\end{array}$ & A $(\mathrm{mm})$ & B $(\mathrm{mm})$ & \multirow{2}{*}{ Ket. } \\
\hline $1(0 \mathrm{~mm})$ & $-3,9045$ & 1,2945 & \\
\hline $2(20 \mathrm{~mm})$ & $-1,8504$ & 0,9 & \\
\hline $3(40 \mathrm{~mm})$ & 0,0566 & 0,7537 & \\
\hline $4(60 \mathrm{~mm})$ & 0,3495 & 0,9812 & \\
\hline $5(80 \mathrm{~mm})$ & 0,4232 & 1,1363 & \\
\hline $6(100 \mathrm{~mm})$ & 0,7074 & 1,104 & \\
\hline $\begin{array}{c}\text { Nilai rata- } \\
\text { rata }\end{array}$ & $-0,703$ & 1,02 & \\
\hline \multicolumn{2}{|c|}{} \\
\hline
\end{tabular}


Nilai penyimpangan yang telah disebutkan di atas adalah untuk penggunaan $3 D$ Scanner Konica Minolta Vivid 9i dengan tipe lensa tele. Pada penggunaan tipe lensa yang lain (wide maupun middle) tentunya nilai yang dihasilkan akan berbeda. Pada penggunaan dengan tipe lensa tele serta dalam kondisi yang dipersyaratkan pada buku manual VI-9i, kecermatan dan kepresisian data kumpulan titik/point clouds yang dihasilkan pada jarak 1 meter secara berurutan adalah $\pm 0,10$ $\mathrm{mm}$ dan \pm 0,024 $\mathrm{mm}$ (Manual, n.d.). Meskipun demikian dalam proses pengolahan data/fitting, nilai penyimpangan yang dihasilkan tidak sama dengan nilai yang tertera di dalam buku manual terutama mengenai kesalahan dikarenakan adanya pergeseran/bias pada objek referensi, lihat Gambar 9.

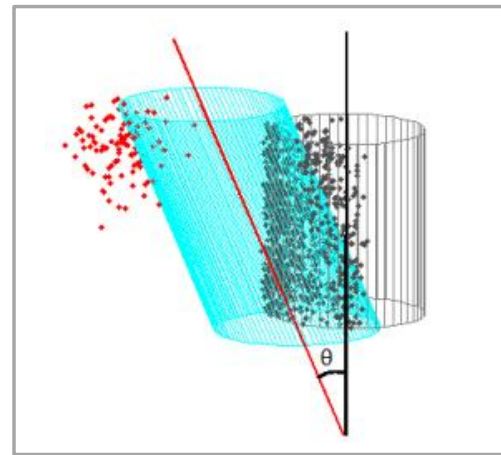

Gambar 9. Kesalahan akibat bias: referensi berwarna merah (Nurunnabi, Sadahiro, and Lindenbergh 2017)

Selain itu keterbatasan lainnya yang masih dijumpai pada proses pengolahan data scanning adalah penentuan referensi. Referensi yang digunakan baik berbasis sumbu maupun "pick point" harus dipilih salah satu pada proses penggabungan datanya.

\section{KESIMPULAN}

Hasil proses pengambilan data scan 3D sebuah objek merupakan kumpulan data titik yang memiliki informasi yang spesifik yang berkaitan dengan kualitas lensa yang digunakan maupun metode penggabungan kumpulan data titik tersebut. Tingkat akurasi pada lensa ditunjukkan oleh ukuran panjang dan tinggi (data titik) yang dihasilkan oleh $3 D$ laser scanner, sedangkan ketebalan (dimensi lebar) dan bentuk lain seperti diameter/radius adalah merupakan indikator kualitas proses penggabungan/fitting.

Di dalam pemilihan referensi sumbu/vektor pada proses penggabungan data titik seharusnya memiliki tingkat akurasi yang tinggi dibandingkan dengan referensi berupa titik/"pick point" apabila kualitas bentuk referensi (botol/silinder) tidak mengalami distorsi. Terdapat beberapa faktor yang mempengaruhi bentuk dan kualitas pengambilan citra objek scan 3D, antara lain karena faktor lingkungan. Pengaruh pencahayaan maupun pemberian cairan developer yang tidak rata serta sifat benda yang mengkilap/memantulkan cahaya adalah faktor yang dapat mengurangi kualitas hasil scan 3D. Apabila terdapat distorsi yang relatif besar pada proses pengolahan data scan dengan metoda sumbu/vektor, maka penyimpangan pada proses fitting akan sangat besar jika dibandingkan dengan metoda pengolahan data menggunakan referensi berupa titik/"pick point". Metode point clouds fitting baik bagi sumbu/vektor maupun "pick point" harus menggunakan jumlah referensi yang bersifat bukan tunggal (minimal 3 buah) maka adanya distorsi pada fitting data titik dengan metode sumbu/vektor dapat diminimumkan, ditandai dengan nilai penyimpangan hasil ukur yang lebih kecil daripada yang dapat dicapai dalam metode fitting menggunakan "pick point".

\section{SARAN}

Penelitian lanjutan bagi objek berukuran tipis (sudu/blade) akan lebih akurat menggunakan Coordinate Measuring Machine (CMM). Hasilnya bisa diperbandingkan dengan hasil yang diperoleh pada proses scsanning dan hasil pengukuran objek secara langsung. Selain itu juga perlu dilakukan kajian secara ilmiah yang berkaitan dengan pengaruh faktor lingkungan (eksternal) dalam proses scanning objek.

\section{DAFTAR PUSTAKA}

Chen, Tianfan, Chenghui Gao, and Bingwei He. 2014. "Point Cloud Registration Method Based on Face-Mating after Denosing" 537: 131-35.

https://doi.org/10.4028/www.scientific.net/ AMM.536-537.131.

Dewi, Dyah Kusuma, and Harry Purnama. 2018. "REKAYASA BALIK SUDU TURBIN DENGAN PERANGKAT LUNAK CATIA 
MENGGUNAKAN KURVA BEZIER

TURBINE BLADE REVERSE WITH

CATIA SOFTWARE USING BEZIER

CURVE." Majalah Ilmiah Pengkajian

Industri 12 (1): 1-8.

Manual, Instruction. n.d. "NON-CONTACT 3D DIGITIZER."

Nurunnabi, Abdul, Yukio Sadahiro, and Roderik Lindenbergh. 2017. "Delft University of Technology Robust Cylinder Fitting in Three-Dimensional Point Cloud Data ROBUST CYLINDER FITTING IN THREE-DIMENSIONAL POINT CLOUD DATA." International Archives of the Photogrammetry, Remote Sensing and Spatial Information Sciences. https://doi.org/10.5194/isprs-archives-XLII1-W1-63-2017.

Pujiyanto, V. Shinta. 2014. "PENYUSUNAN ( FITTING ) DATA TITIK ( POINT CLOUD ) DARI PROSES PEMINDAIAN ( SCANNING ) 3 DIMENSI PADA PRODUK CYLINDER HEAD COVER.” Metal Indonesia $36 \quad$ (2): 3. https://doi.org/10.32423/jmi.2014.v36.8489.

Suryo, Yoedo Ageng, Eko Mulyanto, Ahmad Zaini, and I Ketut Eddy Purnama. 2013. "Registrasi Point Cloud Objek Berkontur Menggunakan Metode Red Green Blue Color Iterative Closest Point" 11 (2): 9-13.

Wang, Zhen, Yueqi Zhong, Kaijie Chen, Jiayi Ruan, and Jincheng Zhu. 2014. "3D Human Body Data Acquisition and Fit Evaluation of Clothing" 994: 4161-64. https://doi.org/10.4028/www.scientific.net/ AMR.989-994.4161.

Yu, Changzhi, Fang Ji, and Junpeng Xue. 2020. "Cutting Plane Based Cylinder Fitting Method With Incomplete Point Cloud Data for Digital Fringe Projection." https://doi.org/10.1109/ACCESS.2020.3016 424.

Yu, Hongmei, and Ziqi Wang. 2014. "Technology of Mobile Phone 3D Model Reconstruction Based on the Geomagic Studio" 973: 135760. https://doi.org/10.4028/www.scientific.net/ AMR.971-973.1357.

Yusmira, Herwan. 2016. "Reverse Engineering Blok Silinder , Comp-Head Genset X Dan
Pengaruh Developer Terhadap Hasil 3D Scanning," 31-41. 